\title{
Makalah Tugas Akhir \\ PERANCANGAN SISTEM PAKAR PENDIAGNOSIS KERUSAKAN LAPTOP DI "DINAR COMP" BERBASIS WEB DENGAN PHP DAN MYSQL
}

Wandri Okki Saputra $^{1)}$, R. Rizal Isnanto ${ }^{2)}$, Ike Pertiwi Windasari ${ }^{2)}$

Program Studi Sistem Komputer, Fakultas Teknik, Universitas Diponegoro, Jln. Prof. Sudharto, Tembalang, Semarang, Indonesia email :wandriokki@gmail.com

\begin{abstract}
Abstrak - Saat sekarang ini laptop sudah menjadi kebutuhan di kalangan pelajar, mahasiswa, karyawan dan profesi lainya. Suatu saat laptop tersebut akan mengalami kerusakan dan diperlukan seorang pakar untuk mendiagnosis kerusakan tersebut. Aplikasi sistem pakar merupakan salah satu aplikasi untuk diagnosis kerusakan laptop seperti kemampuan seorang pakar. Dengan adanya sistem pakar, dapat membantu pengguna untuk bisa mendiagnosis kerusakan laptop tanpa harus di diagnosis oleh pakar.

Dalam perancangan aplikasi, metode yang digunakan adalah metode waterfall. Metode ini sangat tepat dalam pembuatan aplikasi seperti ini karena mempunyai alur yang memungkinkan perancang untuk mengevaluasi aplikasi tanpa harus mengubah dari dasar. Sedangkan tahapan dalam pembuatan aplikasi ini menggunakan beberapa tahap yaitu studi pustaka dan bimbingan, pengambilan data dan analisa (wawancara, pengamatan dan berkas informasi), perancangan, pembuatan sistem dan terakhir implementasi.

Berdasarkan hasil pengujian alpha dan betha, aplikasi yang dibangun sudah berjalan cukup maksimal, tetapi tidak menutup kemungkinan dapat terjadi kesalahan dan kekurangan pada saat aplikasi digunakan.
\end{abstract}

Kata Kunci : Sistem Pakar, Laptop, Pengguna, Pakar

\subsection{Latar Belakang \\ I. PENDAhUluan \\ Kemajuan teknologi saat ini dapat mempermudah} pekerjaan manusia, karena saat sekarang ini kita dapat membuat sebuah kecerdasan buatan yang salah satunya disebut sistem pakar. Dalam pengimplementasianya sistem pakar disini dapat menggantikan peran seorang pakar, karena pengetahuan seorang pakar dapat di implementasikan kedalam sistem untuk dapat digunakan oleh orang lain yang bukan pakar.

Ide dasar serta manfaat dari sistem pakar dalam membantu pekerjaan manusia khususnya pakar inilah yang menjadi sudut pandang dari penulis yang dijadikan sebagai objek dalam tulisan ini. Pada penelitian ini penulis melakukan penelitian untuk membuat sistem pakar yang bisa mendiagnosis kerusakan pada laptop. Karena saat sekarang ini laptop sudah menjadi kebutuhan di kalangan pelajar, mahasiswa, karyawan dan profesi lainya. Suatu saat laptop tersebut akan mengalami kerusakan dan diperlukan seorang pakar untuk mendiagnosis kerusakan pada laptop tersebut.

Pengatahuan mendiagnosis dari seorang pakar itulah yang dapat diaplikasikan kedalam suatu sistem aplikasi komputer yang biasa disebut sistem pakar agar dapat

1) Mahasiswa Sistem Komputer UNDIP

2) Dosen Sistem Komputer UNDIP digunakan oleh orang lain. Dengan dibangunya sistem pakar berbasis web ini dapat memberikan kebebasan akses dimanapun dalam membantu pelanggan untuk bisa mendiagnosis kerusakan pada laptop sebelum membawanya ke toko servis untuk di tangani lebih lanjut oleh pakar dari toko komputer dan servis Dinar Comp.

\subsection{Rumusan Masalah}

Berdasarkan latar belakang masalah tersebut dapat dibuat suatu rumusan masalah yaitu:

"Bagaimana merancang dan membangun suatu sistem pakar untuk mendiagnosis kerusakan pada laptop yang bisa langsung digunakan oleh pelanggan toko komputer dan servis laptop Dinar Comp berbasis web dengan menggunakan bahasa pemrograman PHP dan MySQL sebagai basis data"

\subsection{Tujuan}

Tujuan dari tugas akhir ini adalah adalah menciptakan perangkat lunak sistem pakar pendiagnosis kerusakan laptop berbasis web untuk membantu pelanggan dalam mendiagnosis kerusakan laptop sebelum membawanya ke toko komputer dan servis Dinar Comp untuk ditangani lebih lanjut oleh pakar.

\subsection{Batasan Masalah}

Untuk menghindari pembahasan yang meluas, maka ditetapkan batasan-batasan masalah sebagai berikut: 1. Semua data gejala, kerusakan, penyebab dan solusi yang menjadi basis pengetahuan untuk mendiagnosis kerusakan laptop yang sering dan biasa dikerjakan oleh pakar di toko komputer dan servis Dinar Comp.

2. Kerusakan pada laptop pelanggan yang tidak dapat di diagnosis oleh sistem pakar, akan langsung di bawa ke toko oleh pelanggan untuk di diagnosis lebih lanjut oleh pakar.

3. Menggunakan pendekatan pelacakan runut maju (forward chaining).

4. Pelanggan menjawab pertanyaan sistem dengan memilih jawaban ya atau tidak.

5. Pembuatan sistem pakar menggunakan bahasa pemrograman PHP dengan tool Adobe Dreamweaver dan MySQL sebagai basis data.

6. Sistem ini ditujukan untuk pelanggan yang kurang memahami laptop, tetapi mengetahui setidaknya 
nama-nama perangkat laptop beserta bentuk fisiknya.

\subsection{Definisi Sistem Pakar}

\section{DASAR TEORI}

Sistem pakar adalah suatu program komputer yang dirancang untuk memodelkan kemampuan penyelesaian masalah yang dilakukan oleh seorang pakar[3].

\subsection{Struktur Sistem Pakar}

Sistem pakar terdiri dari dua bagian utama, yaitu lingkungan pengembangan (development environment) dan lingkungan konsultasi (consultation environment)[5].

2.3 Komponen Sistem Pakar

1. Antarmuka Pengguna (User Interface)

Antarmuka Pengguna merupakan mekanisme yang digunakan oleh pengguna dan sistem pakar untuk berkomunikasi.

2. Basis Pengetahuan

Basis pengetahuan mengandung pengetahuan untuk pemahaman, formulasi dan penyelesaian masalah.

3. Akuisisi Pengetahuan

Akuisisi pengetahuan adalah akumulasi, transfer dan transformasi keahlian dalam menyelesaikan masalah dari sumber pengetahuan ke dalam program komputer.

4. Mesin Inferensi

Mesin inferensi adalah program komputer yang memberikan metodologi untuk penalaran tentang informasi yang ada dalam basis pengetahuan dan dalam workplace untuk memformulasikan kesimpulan. Dalam perancangan sistem pakar ini penulis menggunakan metode runut maju (forward chaining). Merupakan proses perunutan yang dimulai dengan menampilkan kumpulan data atau fakta yang meyakinkan menuju kesimpulan akhir[5].

5. Memori Kerja

Merupakan bagian dari sistem pakar yang menyimpan fakta-fakta yang diperoleh saat dilakukan proses konsultasi.

6. Fasilitas Penjelasan

Fasilitas penjelasan adalah komponen tambahan yang akan meningkatkan kemampuan sistem pakar.

7. Perbaikan Pengetahuan

Pakar memiliki kemampuan untuk menganalisis, meningkatkan kinerja dan kemampuan yang semua tersebut adalah penting dalam pembelajaran terkomputerisasi, sehingga program akan mampu menganalisis penyebab kesuksesan dan kegagalan yang akan dialaminya.

\section{ANALASIS DAN PERANCANGAN SISTEM}

\subsection{Analisis Sistem}

Analisis sistem merupakan salah satu proses yang harus dilakukan dalam melakukan perancangan suatu perangkat lunak. Karena di dalam tahap ini merupakan tahap penguraian dari suatu sistem aplikasi yang utuh kedalam bagian komponennya.

\subsubsection{Analisis Masalah}

Kurangnya pengetahuan yang cukup dalam mengetahui kerusakan laptop secara umum melanda hampir semua pengguna. Hal ini mengakibatkan sebagian besar masyarakat umum atau pengguna tidak dapat mengidentifikasi letak kerusakan yang terjadi pada laptopnya. Sehingga banyak sekali pengguna yang mengeluarkan biaya, tenaga dan waktu hanya untuk ke toko servis untuk menanyakan langsung kerusakan laptop kepada seorang pakar laptop. Itu tidak akan terjadi jika dibuat suatu sistem pakar pendiagnosis kerusakan laptop, karena sistem pakar ini dapat melakukan diagnosis kerusakan laptop, pelanggan hanya menjawab beberapa pertanyaan yang ditampilkan di sistem pakar ini.

\subsubsection{Sumber Data}

Data mengenai mendiagnosis kerusakan laptop berasal dari semua data gejala, kerusakan, penyebab dan solusi yang menjadi landasan basis pengetahuan untuk mendiagnosis kerusakan laptop merupakan yang sering dan biasa dikerjakan oleh pakar di toko komputer dan servis Dinar Comp.

\subsubsection{Identifikasi Masalah}

Pada tahapan ini penulis mencoba mengidentifikasi permasalahan yang akan dikaji, dalam hal ini permasalahan pada kerusakan laptop, adapun masalah-masalah yang akan diambil dalam pembangunan aplikasi sistem pakar kerusakan laptop ini adalah gejalagejala yang mengindikasi kerusakan laptop.

\subsubsection{Akuisisi Pengetahuan}

Akuisisi pengetahuan adalah akumulasi, transfer dan transformasi keahlian dalam menyelesaikan masalah dari sumber pengetahuan ke dalam program komputer.

\subsubsection{Konseptualisasi}

Identifikasi kerusakan laptop memang sangat membutuhkan pengalaman dan pengetahuan yang cermat untuk dapat mengenal ciri-ciri kerusakan beserta gejalagejala kerusakan dan sebab-sebab utama kerusakan yang terjadi. Karena banyak sekali gejala-gejala kerusakan yang hampir sama apabila tidak memiliki kejelian dan ketelitian untuk menelusurinya. Oleh karena itu diperoleh suatu konsep untuk mengembangkan sistem pakar ini, yaitu proses identifikasi jenis kerusakan pada laptop dan bagaimana caranya untuk menanggulangi atau menentukan solusi dari kerusakan tersebut.

\subsection{Rancangan / Desain}

Perancangan sistem meliputi perancangan basis pengetahuan, perancangan mesin inferensi, perancangan representasi pengetahuan, perancangan basis data, dan perancangan antarmuka.

\subsubsection{Perancangan Basis Pengetahuan}

Basis pengetahuan merupakan kumpulan pengetahuan bidang tertentu pada tingkat pakar dalam format tertentu. Pengetahuan ini diperoleh dari akumulasi pengetahuan pakar.

Tabel 1 gejala kerusakan

\begin{tabular}{|l|l|}
\hline \multicolumn{1}{|c|}{ Kode } & \multicolumn{1}{c|}{ Nama Gejala } \\
\hline G001 & Tombol power on-off tidak berfungsi \\
\hline G002 & Tampilan gambar pada layar LCD tidak ada \\
\hline G003 & Indikator Led semua mati \\
\hline G004 & Gambar terlihat redup ( samar-samar ) \\
\hline
\end{tabular}


Tabel 1 gejala kerusakan (Lanjutan)

\begin{tabular}{|l|l|}
\hline \multicolumn{1}{|c|}{ Kode } & \multicolumn{1}{c|}{ Nama Gejala } \\
\hline G005 & Kondisi LCD gelap \\
\hline G006 & Muncul pesan "Warning low battery" \\
\hline G007 & $\begin{array}{l}\text { Tampilan gambar kadang muncul, kadang } \\
\text { hilang }\end{array}$ \\
\hline G008 & $\begin{array}{l}\text { Muncul pesan "Warning cmos battrey is low, } \\
\text { press F1 to resume" }\end{array}$ \\
\hline G009 & Layar LCD ada garis horizontal \\
\hline G010 & Garis rooling pada layar LCD \\
\hline G011 & Laptop tiba-tiba restart sendiri \\
\hline G012 & Laptop hang / error \\
\hline G013 & Indikator Led berkedip-kedip \\
\hline G014 & Tampil pesan "unknown disk boot error" \\
\hline G015 & Tampil pesan "Insert properly right disk" \\
\hline G016 & Tampil pesan "Retry boot disk" \\
\hline G017 & Tombol tertentu pada keyboard tidak berfungsi \\
\hline G018 & Bunyi beep saat booting \\
\hline G019 & Suara putus-putus tidak jelas \\
\hline G020 & Muncul pesan "warning USB not recognize" \\
\hline G021 & Mesin hidup sebentar terus mati \\
\hline G022 & Tampilan gambar hanya setengah \\
\hline G023 & Suara ada noise ( terdengar kasar ) \\
\hline G024 & Suara / audio output mati \\
\hline G025 & Wifi ( Wireless ) tidak berfungsi \\
\hline G026 & Tidak dapat terkoneksi jaringan Lan \\
\hline G027 & Port USB tidak berfungsi \\
\hline G028 & Kondisi body laptop panas berlebih \\
\hline G029 & Laptop tampil blue screen \\
\hline G030 & Indikator led battrei saat di charger tidak nyala \\
\hline G031 & Indikator battrei tanda silang \\
\hline G032 & Keyboard tidak berfungsi \\
\hline G033 & Touchpad / Mouse tidak berfungsi \\
\hline G034 & Battrei tidak terisi \\
\hline G035 & Layar LCD tampil putih ( White screen ) \\
\hline G036 & Laptop mati total ( matot ) \\
\hline G037 & Laptop tiba-tiba mati sendiri \\
\hline G038 & Windows (OS) hang / error / Lambat \\
\hline
\end{tabular}

Tabel 2 Kerusakan pada laptop

\begin{tabular}{|l|l|}
\hline Kode & \multicolumn{1}{c|}{ Nama Kerusakan } \\
\hline K001 & Gangguan pada Mainboard Laptop \\
\hline K002 & Gangguan pada LCD / LED \\
\hline K003 & Gangguan pada Charger / Adaptor DC \\
\hline K004 & Gangguan pada Fan Processor / Processor \\
\hline K005 & Gangguan pada Sistem Windows ( OS ) \\
\hline K006 & Gangguan pada Keyboard / Touchpad-Mouse \\
\hline K007 & Gangguan pada RAM / Sdimm memory \\
\hline K008 & Gangguan pada Port USB / LAN / WIFI \\
\hline K009 & Gangguan pada Harddisk Laptop \\
\hline K010 & Gangguan pada IC Sound / Speaker Internal \\
\hline K011 & Gangguan pada Baterai Laptop \\
\hline K012 & Gangguan pada Instalasi Driver \\
\hline
\end{tabular}

\subsubsection{Perancangan Representasi Pengetahuan}

Representasi pengetahuan dimaksudkan untuk mengorganisasikan basis pengetahuan dalam bentuk dan format tertentu untuk bisa dimengerti oleh komputer.

Tabel 3 Kaidah produksi

\begin{tabular}{|c|l|}
\hline No & \multicolumn{1}{|c|}{ Aturan } \\
\hline 1 & R1 : IF (G001) OR (G003) OR (G007) OR (G008) \\
& OR (G011) OR (G012) OR (G013) OR (G014) OR \\
& (G015) OR (G016) OR (G018) OR (G021) OR \\
& (G036) OR (G037) THEN K001 \\
\hline 2 & R1 : IF (G002) OR (G004) OR (G005) OR (G009) \\
& OR (G010) OR (G022) OR (G034) THEN K002 \\
\hline 3 & R1 : IF (G030) OR (G034) OR (G037) THEN K003 \\
\hline
\end{tabular}

Tabel 3 Kaidah produksi (Lanjutan)

\begin{tabular}{|c|l|}
\hline No & \multicolumn{1}{|c|}{ Aturan } \\
\hline 4 & $\begin{array}{l}\text { R1 }: \text { IF (G011) OR (G012) OR (G021) OR (G028) } \\
\text { OR (G037) THEN K004 }\end{array}$ \\
\hline 5 & $\begin{array}{l}\text { R1 }: \text { IF (G012) OR (G019) OR (G029) OR (G038) } \\
\text { THEN K005 }\end{array}$ \\
\hline 6 & $\begin{array}{l}\text { R1 }: \text { IF (G017) OR (G025) OR (G032) OR (G033) } \\
\text { THEN K006 }\end{array}$ \\
\hline 7 & $\begin{array}{l}\text { R1 : IF (G011) OR (G013) OR (G018) OR (G029) } \\
\text { THEN K007 }\end{array}$ \\
\hline 8 & R1 : IF (G020) OR (G026) OR (G027) THEN K008 \\
\hline 9 & R1 : IF (G014) OR (G015) OR (G016) THEN K009 \\
\hline 10 & R1 : IF (G019) OR (G023) OR (G024) THEN K010 \\
\hline 11 & $\begin{array}{l}\text { R1 : IF (G006) OR (G022) OR (G030) OR (G031) } \\
\text { OR (G034) THEN K011 }\end{array}$ \\
\hline 12 & $\begin{array}{l}\text { R1 : IF (G019) OR (G020) OR (G023) OR (G024) } \\
\text { OR (G025) OR (G026) THEN K012 }\end{array}$ \\
\hline
\end{tabular}

\section{IMPLEMENTASI}

\subsection{Implementasi}

Tahap implementasi sistem merupakan tahap menerjemahkan perancangan berdasarkan hasil analisa dalam bahasa yang dapat dimengerti oleh mesin serta penerapan perangkat lunak pada keadaan yang sesungguhnya.

\subsubsection{Perangkat Keras}

Perangkat keras yang digunakan dalam pengujian aplikasi sistem pakar pendiagnosis kerusakan laptop berbasis web memiliki spesifikasi sebagai berikut :

a. Prosesor Intel Core 2 Duo @ $2.20 \mathrm{GHz}$

b. RAM $1 \mathrm{~GB}$

c. HDD 320 SATA

Dalam menjalankan aplikasi ini, spesifikasi perangkat keras yang digunakan tidak harus menggunakan spesifikasi diatas, tetapi juga bisa menggunakan spesifikasi dibawahnya atau diatasnya.

\subsubsection{Perangkat Lunak}

Perangkat lunak yang digunakan dalam pengujian aplikasi sistem pakar pendiagnosis kerusakan laptop berbasis web memiliki spesifikasi sebagai berikut:

1. Sistem Operasi Microsoft Windows 7 Profesional 32 bit.

2. Dalam perancangan basis data menggunakan MySQL.

3. Bahasa pemrograman menggunakan PHP dengan tool editor Adobe Dreamweaver 8.

\subsubsection{Implementasi Antarmuka}

Implementasi antarmuka menggambarkan tampilan dari aplikasi yang dibangun yaitu implementasi antarmuka sistem pakar pendiagnosis kerusakan laptop berbasis web.

1. Tampilan antarmuka halaman user

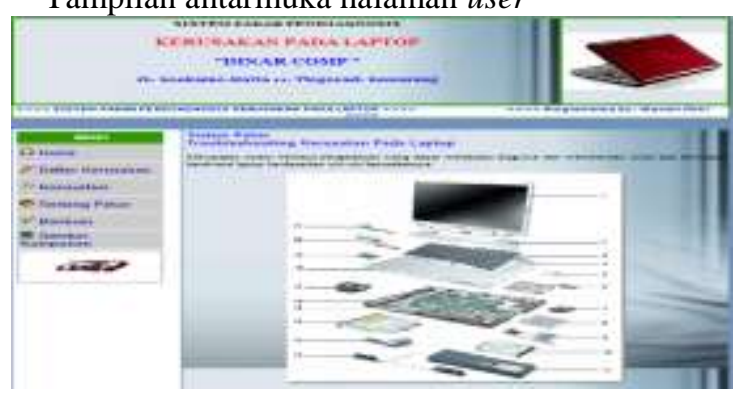

Gambar 1 Tampilan menu utama 


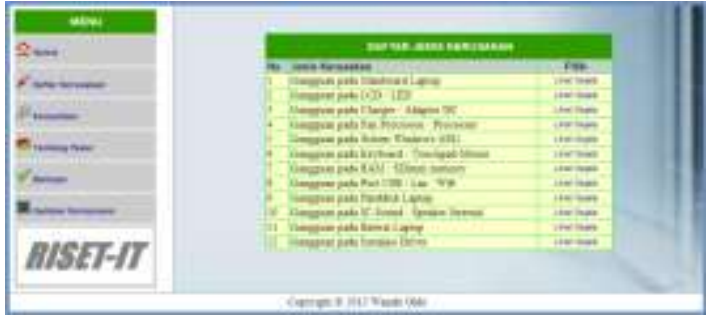

Gambar 2 Tampilan menu daftar kerusakan

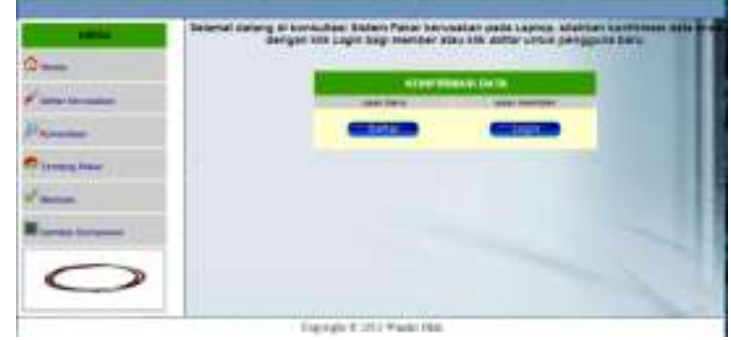

Gambar 3 Tampilan menu konsultasi

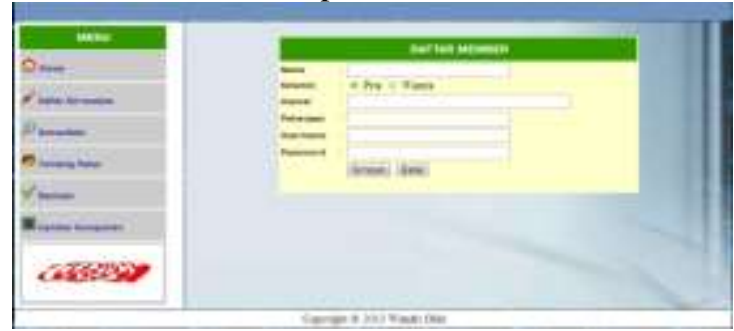

Gambar 4 Tampilan menu konsultasi (daftar) user

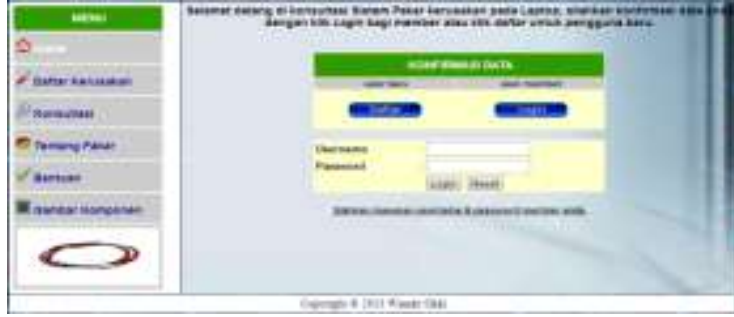

Gambar 5 Tampilan menu konsultasi (login) user

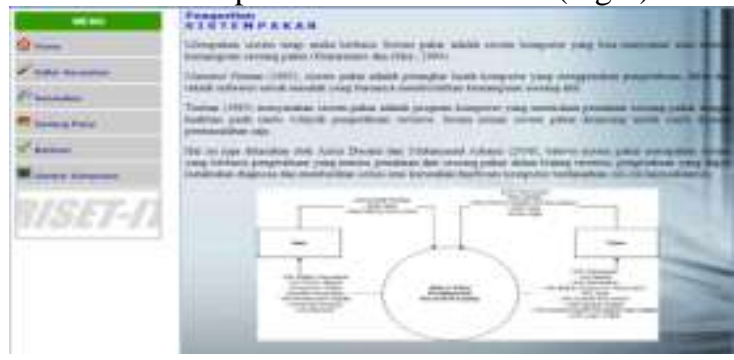

Gambar 6 Tampilan menu tentang pakar

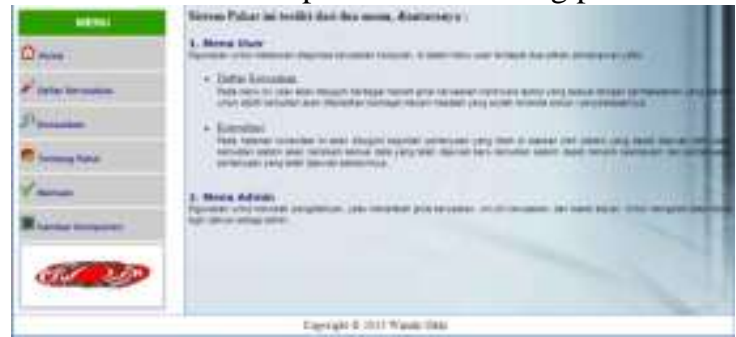

Gambar 7 Tampilan menu bantuan

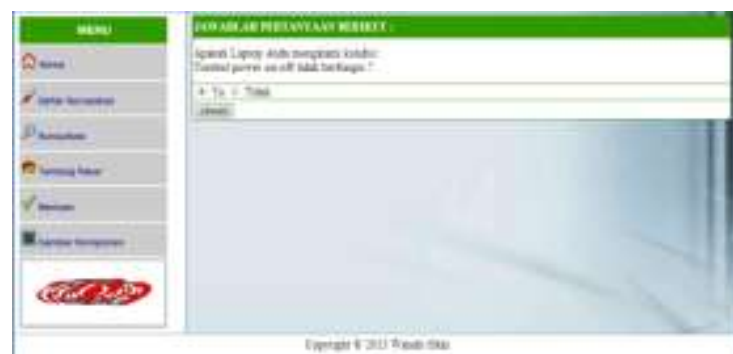

Gambar 8 Tampilan pertanyaan konsultasi

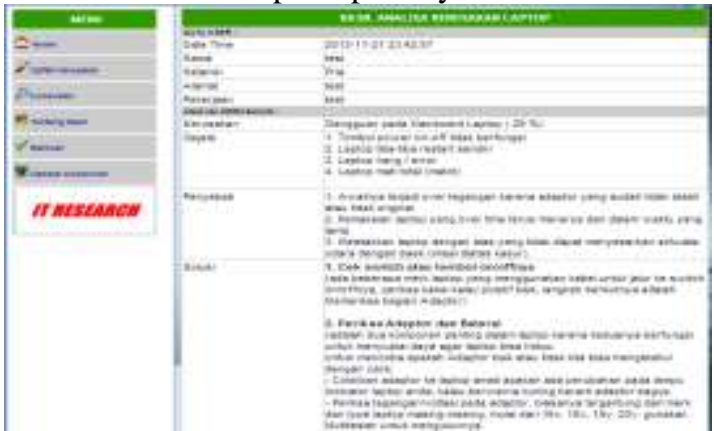

Gambar 9 Tampilan antarmuka hasil konsultasi

2. Tampilan Antarmuka Halaman Pakar/Admin
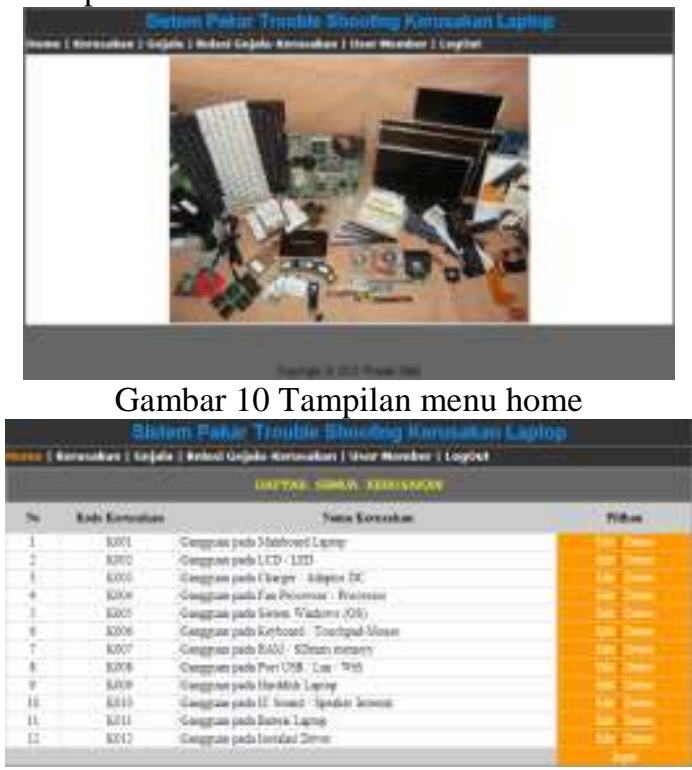

Gambar 11 Tampilan menu data kerusakan

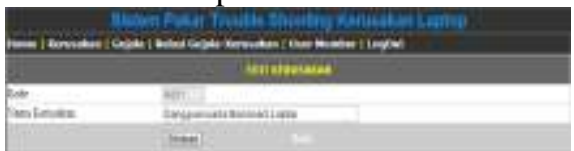

Gambar 12 Tampilan ubah data kerusakan

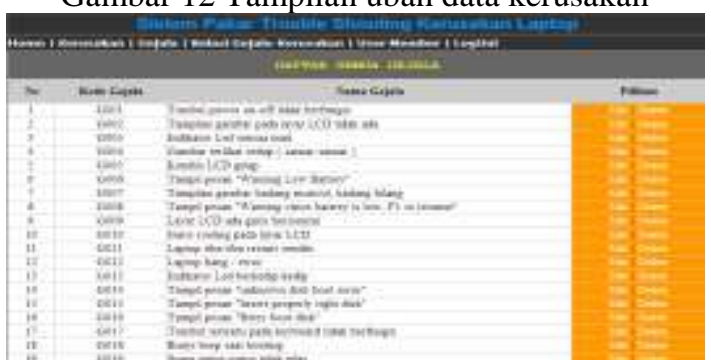

Gambar 13 Tampilan menu data gejala 


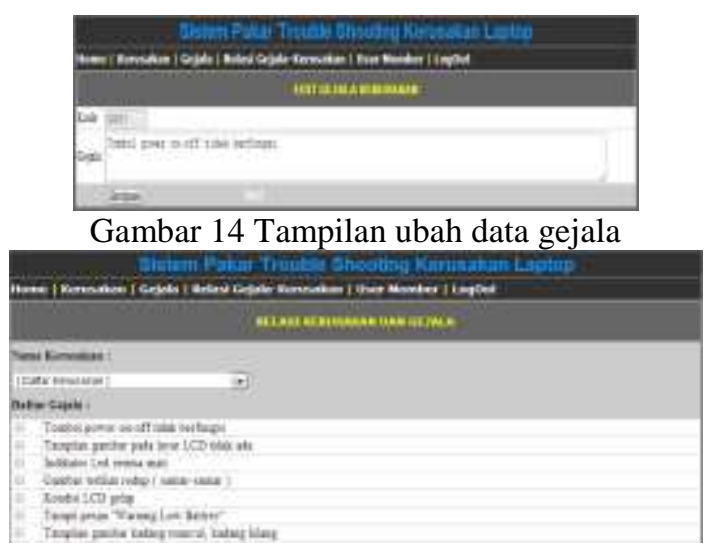

Gambar 15 Tampilan menu data relasi

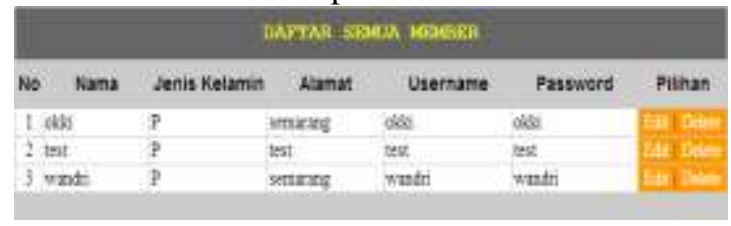

Gambar 16 Tampilan menu data user

\subsection{Pengujian Black Box}

Proses pengujian black box adalah pengujian yang dilakukan dengan cara menguji aplikasi dengan memasukkan data ke dalam form-form yang telah disediakan. Pada tahap ini merupakan kelanjutan dari tahap implementasi. Pengujian yang akan dilakukan dengan cara alpha yaitu dengan metode pengujian black box yang berfokus pada persyaratan fungsional perangkat lunak. Pengujian ini memungkinkan perekayasa sistem mendapatkan serangkaian kondisi input yang sepenuhnya semua persyaratan fungsional untuk suatu program.

\subsubsection{Kesimpulan Hasil Pengujian Alpha}

Berdasarkan hasil pengujian alpha yang telah dilakukan dapat ditarik kesimpulan bahwa aplikasi sudah berjalan cukup maksimal, tetapi tidak menutup kemungkinan dapat terjadi kesalahan pada suatu saat aplikasi digunakan. Sehingga membutuhkan proses maintenance untuk lebih mengetahui kekurangan dari aplikasi.

\subsubsection{Kesimpulan Hasil Pengujian Betha}

Berdasarkan hasil prosentase diatas didapatkan dari pengujian betha, yang dibagikan kepada 20 orang yang mengatakan bahwa perangkat lunak yang dibangun sudah mudah digunakan, mudah untuk dipelajari, tampilan antarmuka menarik, cukup membantu dalam mengidentifikasi kerusakan, gejala dan kerusakan pada aplikasi ini sesuai dengan kenyataan, dan menghasilkan kesimpulan yang cukup akurat.

\section{KESIMPULAN}

1. Aplikasi dibangun berbasis dengan bahasa pemrograman PHP dan basis data MySQL.

2. Basis pengetahuan sistem pakar berdasarkan kerusakan laptop dan gejala yang sering ditangani oleh pakar dari toko komputer dan servis "Dinar Comp".

3. Berdasarkan hasil prosentase dari pengujian betha, perangkat lunak yang dibangun sudah mudah digunakan, mudah untuk dipelajari, tampilan antarmuka menarik, cukup membantu dalam mengidentifikasi kerusakan, gejala dan kerusakan pada aplikasi ini sesuai dengan kenyataan, dan menghasilkan kesimpulan yang cukup akurat.dan aplikasi dapat berjalan dengan baik.

4. Berdasarkan hasil pengujian alpha, perangkat lunak yang dibangun sudah berjalan cukup maksimal, tetapi tidak menutup kemungkinan dapat terjadi kesalahan pada suatu saat aplikasi digunakan. Sehingga membutuhkan proses maintenance untuk lebih mengetahui kekurangan dari aplikasi.

5. Aplikasi sistem pakar pendiagnosis kerusakan laptop ini merupakan pengaplikasian kemampuan dan pengalaman seorang pakar dalam mendiagnosis kerusakan laptop dalam bentuk suatu aplikasi yang dapat digunakan oleh pelanggan untuk mendiagnosis kerusakan laptop.

\section{SARAN}

Berdasarkan pengujian terhadap aplikasi sistem pakar pendiagnosis kerusakan laptop yang telah dibuat, dapat diberikan beberapa saran sebagai berikut.

1. Aplikasi sistem pakar pendiagnosis kerusakan laptop ini dapat dikembangkan lebih lanjut dengan menambahkan beberapa fitur yang belum dimasukkan ke dalam aplikasi.

2. Ruang lingkup sistem dalam melakukan identifikasi suatu kerusakan dapat dikembangkan menjadi lebih luas dan lebih kompleks terutama memperbanyak pertanyaan-pertanyaan gejala sehingga dapat menghasilkan kesimpulan yang lebih akurat dan dapat mengatasi permasalahan laptop yang cukup kompleks.

3. Memperbaiki dan memperindah tampilan antarmuka untuk menyajikan kenyamanan penggunaan oleh user.

4. Menyajikan solusi kerusakan hardware yang lebih detil dengan langkah-langkah penanganan yang rinci dan disertai dengan gambar.

\section{DAFTAR PUSTAKA}

Buku

Al Fatta, Hanif. 2007. Analisis dan Perancangan Sistem Informasi untuk Keunggulan Bersaing Perusahaan dan Organisasi Modern. CV. Andi Offset.Yogyakarta.

Kusumadewi, Sri. 2003. Artificial Inteligence Teknik dan Aplikasi Edisi Pertama. Penerbit Graha Ilmu. Yogyakarta.

Kusrini. 2006. Sistem Pakar Teori dan Aplikasi. Penerbit Andi. Yogyakarta.

Arhami, Muhammad. 2005. Konsep Dasar Sistem Pakar. Penerbit Andi. Yogyakarta.

Hartati, Sri dan Sari Iswanti. 2008. Sistem Pakar dan Pengembanganny. Graha Ilmu. Yogyakarta.

Kusrini. 2008. Aplikasi Sistem Pakar. Penerbit Andi. Yogyakarta.

Whitten, Jeffrey L dkk. 2004. Metode Desain dan Analisis Sistem Edisi 6 Bahasa Indonesia. CV. Andi Offset. Yogyakarta.

Nugroho, Bunafit. 2004. Aplikasi Pemrograman Web Dinamis dengan PHP dan MySQL. Gava Media. Yogyakarta.

Kadir, Abdul. 2008. Dasar Pemrograman Web Dinamis Menggunakan PHP. CV. Andi Offset. Yogyakarta.

Hirin A.M dan Virgi. 2011. Cepat Mahir Pemrograman Web dengan PHP dan MySQL. Prestasi Pustakaraya. Jakarta. 
Jurnal

Anastasia Lubis, Sintha. 2011. Sistem Pakar Untuk Menelusuri Kerusakan Pada Komputer dengan Microsoft Visual Basic 6.0. Universitas Sumatera Utara. Medan.

\section{BIODATA PENULIS}

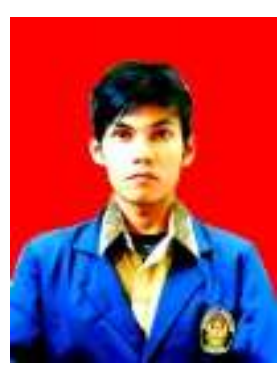

Wandri Okki Saputra, lahir di Sungai Rumbai pada 21 Oktober 1991. Telah menempuh pendidikan di TK Islam Harapan Bunda, SD N 48 Sungai Rumbai, MTs N Koto Baru, SMA N 1 Sungai Rumbai, dan sekarang tengah menyelesaikan pendidikan Strata Satu di Jurusan Teknik Sistem Komputer Fakultas Teknik, Universitas Diponegoro, Semarang, Indonesia Angkatan Tahun 2009.

Mengetahui/Mengesahkan

Dosen Pembimbing I

Dr. R. Rizal Isnanto,S.T., M.M., M.T.

NIP. 197007272000121001

Mengetahui/Mengesahkan

Dosen Pembimbing II

Ike Pertiwi Windasari, S.T., M.T.

NIP. 198412062010122008 